\title{
Guidelines For The Individual Education Plan In Special Schools and Inclusive Elementary Schools
}

\author{
Mega Iswari *), Nurhastuti , Zulmiyetri ,Kasiyati \\ Universitas Negeri Padang \\ *)Corresponding author, $\equiv$ mega iswari@yahoo.com
}

\section{Revisi 5/07/2019; \\ Diterima 5/08/2019; \\ Publish 05/09/2019}

Kata kunci: Asesmen, Program Pembelajaran Individual, Anak Berkebutuhan Khusus

\begin{abstract}
Abstrak
Guru-guru Sekolah Luar Biasa dan Sekolah Dasar penyelenggara pendidikan inklusi di Bukitinggi perlu memahami cara melakukan asesmen dan mengusun program pembelajaran individual bagi peserta didik berkebutuhan khusus sesuai dengan hasil asesmen. Sedangkan guru-guru tersebut dituntut untuk mampu dan terampil dalam menyusun program pembelajaran individual berdasarkan hasil asesmen agar perkembangan akademik maupun non akademik peserta didik berkebutuhan khusus berkembang dengan baik. Program Pembelajaran Individual merupakan uraian kegiatan-kegiatan dalam bidang pendidikan dalam rangka memenuhi kebutuhan khusus individu peserta didik dan menguraikan bentuk pelayanan pendidikan yang dirancang secara rinci untuk menemukan kebutuhan khusus dalam bidang pendidikan bagi peserta didik berkebutuhan khusus, jadi disini terlihat ada upaya yang sengaja dirancang untuk menutupi kelemahan yang dihadapi peserta didik dalam proses pendidikan di sekolah. Hasil pantauan dan evaluasi yang dilakukan oleh tim pengabdian dapat di paparkan bahwa kegiatan pembelajaran indivdual telah berjalan dengan baik dan sesuai dengan program pembelajaran invividual yang telah di latihkan. Sehingga semua guru sangat merasa puas dan senang dengan materi yang diperolehnya serta berterima kasih pada Tim pengabdian telah memberikan pengetahuan yang sangat bermanfaat untuk memberikan pelayanan pendidikan yang sesuai dengan kebutuhan anak dalam melaksanakan kegiatan proses pembelajaran bagi anak berkebutuhan khusus. Pada akhirnya guru telah mampu dan mahir dalam melakukan identifikasi, asesmen dan menyusun program pembelajaran berdasarkan hasil asesmen pada anak berkebutuhan khusus agar sesuai program yang sudah dirancang sesuai dengan kemampuan anak berdasarkan asesmen .
\end{abstract}

\section{PENDAHULUAN}

Manusia berbeda-beda bukan hanya dalam umurnya saja, tetapi juga dalam warna kulit, karakteristik, kesenangan, kebiasaan, kemampuan, minat, dan lain-lain, Bagi dunia pendidikan kenyataan ini mengharuskan perlunya pendidik mempertimbangkan perbedaan-perbedaan 


\section{Suluah Bendang: Jurnal Ilmiah Pengabdian Kepada Masyarakat}

Vol.19, No.2, 2019

Mega Iswari, Nurhastuti, Zulmiyetri, Kasiyati

peserta didik ketika merencanakan, melaksanakan, dan menilai pendidikan, Khusus peserta didik berkebutuhan khusus terdapat perbedaan karakteristik dan kemampuan yang sangat unik baik di bidang akademik maupun non-akademik. Implikasi dari perbedaan yang bervariasi dan unik pada anak berkebutuhan khusus tersebut, maka agar potensinya dapat berkembang secara optimal diperlukan bentuk layanan pendidikan yang sesuai dengan kekhususannya. Bentuk layanan pendidikan tersebut dapat menyangkut strategi, metode, media, sarana-prasarana dan lainnya. Sistem layanan pembelajaran yang dapat mengakomodir sesuai kebutuhan dan kemampuan siswa adalah program pembelajaran individual (PPI). Identifikasi merupakan suatu proses di dalam menemukan dan mengenali keberagaman peserta didik..kegiatan identifikasi dibatasi hanya untuk menentukan individu yang diduga mengalami hambatan sehingga belum dapat menjawab pertanyaan potensi apa yang dimiliki peserta didik, hal ini bertujuan untuk melihat kekhususan/hambatan peserta didik dan area fungsi belajar, sosial emosi, komunikasi, dan sensorimotor. Identifikasi ini bertujuan untuk menemukan dan mengenali Peserta Didik Berkebutuhan Khusus (PDBK), ini juga untuk mengkategorikan dan mengklasifikasikan keragaman dari PDBK serta yang baru masuk sekolah maupun yang pndah ke sekolah lain menjadi peserta didik baru

Asesmen merupakan suatu proses yang sistematis dan komprehensif untuk menggali permasalahan lebih lanjut untuk mengetahui apa yang menjadi masalah, hambatan, keunggulan, dan kebutuhan individu. Dimana hasil asesmennya digunakan untuk memberikan layanan pendidikan yang dibutuhkan dengan berdasarkan kepada modalitas (potensi) yang dimiliki individu yang diperlukan dalam menyusun program pembelajaran (Howard and Orlansky (1986). Asesmen ini digunakan untuk menggali informasi yang berkaitan dengan menemukan hambatan, keunggulan dan kebutuhan sebagi dasar untuk menyusun program pembelajaran maupun pembelajaran individual.(PPI)Program pembelajaran individual (PPI) adalah suatu program pembelajaran yang disusun untuk membantu peserta didik yang berkebutuhan khusus sesuai dengan kemampuannya. Program ini terbagi atas dua (2) hal yaitu: Program jangka panjang dan program jangka pendek. Pada program pembelajaran individual (PPI) mencakup kurikulum dan penempatan untuk peserta didik yang berkebutuhan khusus, serta berbagai aspek yang terkait orang tua dan lembaga yang terkait (Amin,1995).

Penerapan program pembelajaran individual (PPI) pada peserta didik berkebutuhan khusus sangat strategis, Rochyadi (2005) mengemukakan beberapa hal yang mendasari pengembangan program pembelajaran individual (PPI) pada anak berkebutuhan khusus yaitu: (1) Anak berkebutuhan khusus dalam belajar berbeda dengan anak normal, makin berat tingkat kecacatannya semakin komplek cara belajarnya. Anak berkebutuhan khusus memerlukan modifikasi dan rentang waktu yang berbeda dibandingkan dengan peserta didik yang normal. (2) Sekolah bertanggung jawab memberikan keterampilan fungsional agar supaya siswa dapat mandiri. Dengan demikian, diharapkan sekolah dapat mengajarkan keterampilan fungsional yang dibutuhkan siswa dalam menjalankan kehidupannya baik di sekolah, di rumah dan di masyarakat. (3) Guru harus berhubungan dengan orangtua peserta didik di dalam menjalankan program maupun evaluasi programnya. (4) Guru sangat berperan dalam pencapaian tujuan pembelajaran. Guru juga harus dapat meyakinkan masyarakat bahwa tujuan materi dalam program pembelajaran individual (PPI) dapat diterima: praktis, efektif, dan manusiawi. (5) Anak berkebutuhan khusus membutuhkan pelayanan pendidikan dengan prinsip-prinsip modifikasi perilaku. 
Dalam sistem pendidikan yang sifatnya individual maupun yang sifatnya klasikal. Bukan hanya siswa yang harus menyesuaikan diri kepada situasi dan subtansi pendidikan, tetapi juga sistem pendidikan yang harus menyesuaikan diri kepada kemampuan, kesulitan, kecepatan, dan minat peserta didik. Artinya anak berkebutuhan khsusus tidak dipaksa menguasai kompetensi yang di luar kemampuannya. Tetapi juga tidak dikurung dalam bahan yang sudah ada karena ada sangkaan apriori bahwa bahan berikutnya terlalu sukar, Anak berkebutuhan khusus juga tidak ditarik-tarik mengajar temannya yang lebih pintar, tetapi juga tidak didiamkan menunggu temannya yang lebih lambat. Siswa yang gagal dalam suatu metode dan teknik mengajar belum tentu akan gagal ke dalam metode dan teknik yang lain.

\section{METODE PELAKSANAAN}

Bimbingan teknis yang dilatihkan pada guru adalah untuk peningkatan kemampuan guru dalam penyusunan program pembelajaran individual bagi anak berkebutuhan khusus. Meningkatkan Pemahaman guru-guru Sekolah Luar Biasa dan guru2 Sekolah Dasar penyelenggaraan pendidikan Inklusi perlu memahami cara melaksanakan indentifikasi, asesmen, dan menyusun PPI berdasarkan hasil asesmen agar pelayanan pendidikan sesuai dengan kemampuan yang di miliki anak.berkebutuhan khusus. Supaya mereka dapat pendidikan dan pengajaran sesuai bakat dan minat yang dimilikinya. .

Metode yang digunakan dalam penyampaian materi asesmen, program pembelajaran individual baik yang bersifat teori maupun praktek adalah sebagai berikut:

\section{Metode Ceramah dan Tanya Jawab}

Metode ini digunakan pada saat pemberian materi pemahaman tentang pengertian identifikasi, tentang asesmen dan pemahaman tentang penyusunan PPI bagi guru-guru dalam memberikan pelayanan pendidikan pada anak berkebutuhan khusus, nara sumber dapat menjajaki kemampuan awal guru atau peserta pelatihan melalui metode tanya jawah, untuk metode ceramah digunakan pada saat pemateri memaparkan materi yang baru bagi peserta pelatihan yang berasal dari sekolah dasar penyelenggara pendidikan inklusi.

\section{Pemberian Tugas}

Metode pemberian tugas dilakukan pada materi melaksanakan asesmen dan menyusun PPI bagi anak berkebutuhan khusus, setelah peserta pelatihan diberikan pengantar dan petunjuk untuk melakssanakan asesmen dan langsung penyusunan PPI yang berdasarkan hasil asesmen, kemudian peserta pelatihan langsung ditugaskan untuk mengimplementasikanya pada anak berkebutuhan khusus baik di SLB mauun di sekolah dasar penyelenggara pendidikan inklusi.

\section{HASIL DAN PEMBAHASAN}

Kegiatan Pengabdian masyarakat ini dilakukan dalam rangka untuk meningkatkan pemahaman guru tentang pembelajaran individual di Sekolah Luar Biasa dan sekolah dasar penyelenggaraan inklusi di Bukititinggi dilaksanakan selama empat hari yaitu hari Jumat dan Sabtu Tanggal 9 juli 13 Juli 2019, 21 juli dan 22 Juli.2019 Jam 08.00 s.d 17.00 WIB. SLB Bukittinggi adalah sekolah yang menyelenggarakan pendidikan bagi anak b erkebutuhan khusus. Kegiatan yang dilakukan tentang asesmen dan penyusunan PPI bagi anak telah terlaksana dengan baik dan lancar, serta mendapat dukungan yang positif dari guru-guru dan kepala sekolah. Dukungan kepala sekolah diwujudkan dengan kehadiran beliau untuk memberikan kata sambutan walaupun di sela-sela kesibukan, Kepala sekolah merasa kegiatan 


\section{Suluah Bendang: Jurnal Ilmiah Pengabdian Kepada Masyarakat}

Vol.19, No.2, 2019

Mega Iswari, Nurhastuti, Zulmiyetri, Kasiyati

pengabdian ini sangat besar manfaatnya bagi guru. Melalui kegiatan ini guru menjadi paham dan banyak berdiskusi tentang berbagai tingkah laku anak berkebutuhan khusus, begitu pula dengan proses pembelajaran yang perlu diperhatikan di atur sesuai kemampuan anak untuk setiap harinya. Disamping itu berbagai macam hal dapat ditularkan kepada guru lainnya yang akan mengembangkan potensi anak. Pihak sekolah juga berharap semoga kegiatan seperti ini dapat dilanjutkan demi pengembangan pendidikan bagi anak berkebutuhan khusus.. Dari awal kegiatan sampai kegiatan selesai guru-guru sangat antusias mengikuti kegiatan, hal ini terbukti dengan banyaknya guru bertanya tentang materi yang dibahas pada saat kegiatan berlangsung. Hasil pelaksanaan kegiatan ini guru-guru sangat merasakan manfaat dari bertambah pengetahuannya tentang cara melaksanakan asesmen dan menyusun program pembelajaran individual sekali gus mampu melaksanakan pengajaran pada anak berkebutuhan khusus. Guruguru sangat berpartisipasi aktif dalam kegiatan ini karena mereka merasa sangat terbantu dengan pemberian materi kegiatan pengabdian ini untuk pelayanan pendidikan pada anak agar mereka berkembang sesuai kemampuan atau potensi yang dimilikinya.

Berdasarkan hasil diskusi guru-guru dengan tim pengabdian pada saat melakukan asesmen dan penyusunan menyususn program pembelajaraan individual berdasarkan hasil asesmen bagi anak berkebutuhan khusus, mereka merasa kegiatan ini sangat penting sekali karena mereka merasa lebih mudah dalam menemukan kemampuan yang dimiliki anak berkebutuhan khusus. Selama ini guru-guru di sekolah penyelenggara pendidikan inklusi merasa bingung dalam melaksanakan identifikasi, asesmen dan menyusun PPI untuk menentukan kemampuan anak, Maka dari itu melalui bimbingan teknis ini guru menambah pengetahuan guru dalam menangani anak berkebutuhan khussus.. Kegiatan bimbingan teknis yang di berikan oleh tim pengabdian dapat meningkatkan pemahaman guru dengan sesmen dan penyusunn PPI dalam proses pembelajaran bagi anak berkebutuhn khuus di sekolah luar biasa dan di sekolah penyelenggara pendidikan inklusi. Hal ini dapat dilihat dari seberapa dampak pencapaian tujuan dan manfaat dari kegiatan ini.

Pencapaian Tujuan.

Adapun tujuan kegiatan untuk meningkatkan pemahaman guru-guru Sekolah Luar dan sekolah dasar penyelenggara pendidikan inklusi. bagi anak berkebutuhan khusus adalah agar guru memiliki pengetahuan dan pemhaman seluk beluk tentang anak berkebutuhan khusus sehingga dalam proses pembelajaran kesehariannya anak dapat mengikuti pembelajaran dengan tepat sesuai bakat dan minat anak dan sesuai potensinya masing-masing. Dengan demikian kegiatan ini otomatis akan membantu anak dalam mengikuti proses pembelajarannya.

kegiatan bimbingan teknis ini telah tercapai dengan baik dimana telah terlihat bertambahnya pengetahuan guru tentang melaksanakan asesmen dan menyususn program pembelajaran individual. Serta mampu mengimplementasikan pada anak didiknya.

Pencapaian Manfaat.

Adapun manfaat kegiatan yaitu:

1. Memberikan pemahaman tentang pengertian identifikasi, asesmen dan penyususnan program pembelajaran, cara melakukan identifikasi, cara mengasesmen kemampuan peserta berkebutuhan khusus. Sekaligus sudah mampu menyusun PPI untuk meningkatkan pelayanan pendidikan pada peserta didik. 
2. Memberikan pemahaman tentang pelayanan pendidikan pada peserta didik berkebutuhan khusus sesuai dengan hasil asesmen. Kegiatan ini telah terlaksana dengan baik

\section{KESIMPULAN}

Kegiatan pengabdian masyarakat ini dapat dikatakan telah terlaksana dengan baik dan lancar. Hal ini dikarenakan guru sangat antusias dalam mengikuti kegiatan ini yaitu tentang bimbingan teknis Asesemen dan penyusunan PPI bagi peserta didik berkebutuhan khusus dapat dikatakan telah mencapai hasil yang menggembirakan. Ini terlihat dari semangat guru-guru dalam mengikuti kegiatan ini. Secara khusus hasil dari kegiatan pengabdian ini dapat disimpulkan sebagai berikut Kegiatan pengabdian masyarakat yang dilaksanakan ini sangat berdampak positif pada guru serta memberikan manfaat yang sangat besar dalam mennyusun PPI yang sesuai untuk peserta didik berkebutuhan khusus, sehingga dalam pelaksanaan proses pembelajarannyapun bisa berjalan dengan lancar.Tanggapan guru-guru terhadap workshop/pelatihan ini dinilai baik, terbukti dari kahadiran yang disiplin dari awal sampai akhir, mengikuti setiap sesi pelatihan dengan aktif dan antusias dalam melaksanakan kegiatan praktek secara maksimal.

\section{DAFTAR PUSTAKA}

Amin, M.,1995. Ortopedagogik Tunagrahita. Jakarta: Depdikbud, Ditjen Dikti, Proyek Pendidikan Guru.

Howard and Orlansky, 1986. Exceptional Children. Colombus: Merril Publishing Company Edisi kedua.

Rochyadi \& Alimin, 2005. Pengembangan Program Pembelajaran Individual Bagi Anak Tunagrahita. Jakarta: Departemen Pendidikan Nasional, Direktorat Jenderal Pendidikan Tinggi. Direktorat P2TK dan KPT. 